\title{
Early breast cancer in elderly women: surgery or primary endocrine therapy?
}

\author{
N Rocco ${ }^{*}$, L lannone, C Rispoli, D De Vito, A Accurso \\ From de Senectute: Age and Health Forum \\ Catanzaro, Italy. 5-7 December 2009
}

\section{Background}

Breast cancer is the most common type of cancer in women. Up to $30 \%$ of all breast cancers are reported to occur in the over 70 year age group and these percentages may increase in the near future as the mean age of the general population grows up.

The standard treatment for early breast cancer in women of all ages was surgery until the late 1970s, when primary endocrine therapy was first described as an alternative to standard therapy for older women (Bradbeer 1983). Primary endocrine therapy means the use of Tamoxifen, without surgery, radiotherapy or chemotherapy.

The incidence of significant co-morbidity is greater in the elderly, making general anaesthesia more hazardous.

\section{Material and methods}

From January 2008 to July 2009 we treated 68 women older than 70 years (mean age 73 years). 59 of them were surgically treated (mastectomy and axillary lymphoadenectomy or conserving surgery and axillary sentinel node biopsy with or without adjuvant endocrine therapy) and 9 of them were treated with primary endocrine therapy ( 7 of them were older than 80 years and two between 70 and 79). 5 of them had been considered unfit for surgery because of their poor general condition and 4 refused surgery. For all them we assessed the oestrogen receptor status, performing a core-biopsy. All women were affected by ER-positive tumours.

\section{Results and discussion}

At a mean follow up of 9 months only one patient of 68 died for causes not related to breast cancer.

Nowadays very few people result unfit for surgery because breast conserving surgery has made morbidity

\footnotetext{
Dipartimento di Chirurgia Generale e Geriatrica ed Endoscopia Diagnostica
} ed Operativa, Università degli Studi di Napoli 'Federico II', Napoli

and mortality rates very low. However we can consider primary endocrine therapy for women with ER-positive tumours with serious co-morbidity or who refuse surgery.

We can assert that in a group of women with reduced life expectancy and ER-positive tumours, primary endocrine therapy may be an appropriate treatment choice. Moreover more trials are needed to evaluate the clinical effectiveness of aromatase inhibitors as primary therapy for old women with ER-positive tumours.

Published: 19 May 2010

\section{Reference}

1. Bradbeer JW, Kyngdon J: Primary treatment of breast cancer in elderly women with Tamoxifen. Clinical Oncology 1983, 9:31-4.

\section{doi:10.1186/1471-2318-10-S1-A31}

Cite this article as: Rocco et al:: Early breast cancer in elderly women: surgery or primary endocrine therapy?. BMC Geriatrics 2010 10(Suppl 1): A31.
Submit your next manuscript to BioMed Central and take full advantage of:

- Convenient online submission

- Thorough peer review

- No space constraints or color figure charges

- Immediate publication on acceptance

- Inclusion in PubMed, CAS, Scopus and Google Scholar

- Research which is freely available for redistribution

Submit your manuscript at www.biomedcentral.com/submit
C Biomed Central 